\title{
Norois
}

Environnement, aménagement, société

\section{Humanitarian Response to Emergency, Risk and Disaster: a Recent History of Lessons Learnt from a United Nations perspective}

Réponse humanitaire à l'urgence, au risque et aux désastres par l'Organisation des Nations Unies : une histoire récente et ses leçons

\section{Frederick Spielberg}

\section{OpenEdition}

\section{Journals}

\section{Electronic version}

URL: https://journals.openedition.org/norois/9251

DOI: $10.4000 /$ norois.9251

ISSN: $1760-8546$

Publisher

Presses universitaires de Rennes

\section{Printed version}

Date of publication: 22 November 2019

Number of pages: $119-125$

ISBN: 978-2-7535-7875-3

ISSN: 0029-182X

\section{Electronic reference}

Frederick Spielberg, "Humanitarian Response to Emergency, Risk and Disaster: a Recent History of Lessons Learnt from a United Nations perspective", Norois [Online], 251 | 2019, Online since 02 January 2022, connection on 14 January 2022. URL: http://journals.openedition.org/norois/9251 ; DOI: https://doi.org/10.4000/norois.9251 


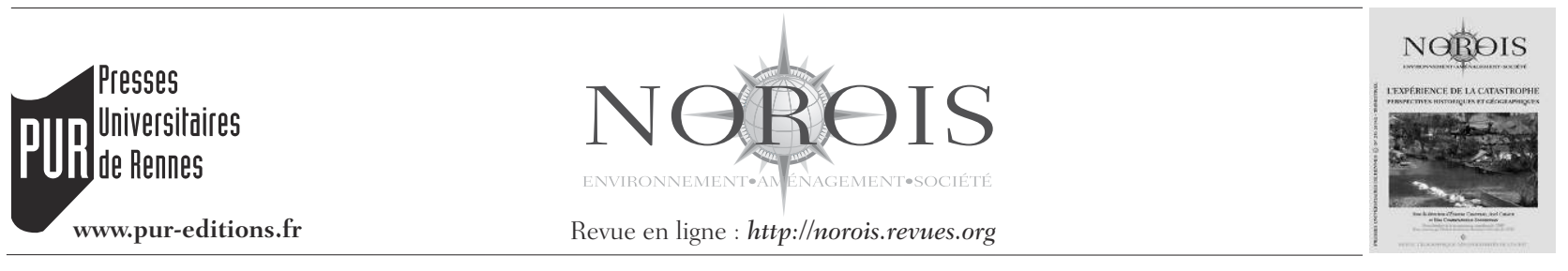

\title{
Humanitarian Response to Emergency, Risk and Disaster: A Recent History of Lessons Learnt from a United Nations Perspective
}

\author{
Réponse humanitaire à l'urgence, au risque et aux désastres \\ par l'Organisation des Nations Unies : une histoire récente et ses leçons
}

\author{
Frederick SpielberG
}

Unicef-Colombia, Calle 72, \#10-71, piso 11, BoGoTÁ, Colombia. (fspielberg@unicef.org) (fspielberg@gmail.com)

\begin{abstract}
In the 75 years since its creation, the United Nations system has developed a comprehensive and layered architecture for managing natural disasters and humanitarian emergencies. The current humanitarian structure-comprised of dozens of specialized agencies, detailed protocols for response, and a focus on managing risk before, during and after major shocks — grew out of several specific experiences, producing important learnings that would be applied later in new contexts. Recently, the system has "re-discovered" key concepts such as building resilience and ensuring accountability to affected populations, in order to save lives and reduce financial losses. To understand the development of the international system of humanitarian action, the article analyses a few lessons from major catastrophes. It also wonders whether the lessons of past disaster responses have indeed been incorporated into the standard operating procedures of the humanitarian system itself.

Résumé : Depuis sa création il y a 75 ans, le système des Nations Unies a développé une structure complète et stratifiée destinée à assurer la gestion des désastres naturels et les urgences humanitaires. La structure humanitaire actuelle - qui comprend une douzaine d'agences spécialisées, des protocoles de réponse détaillés, et se concentre plus particulièrement sur la gestion du risque avant, durant et après l'impact des grandes catastrophes - apparaît comme le résultat de multiples expériences spécifiques, sources de leçons à retenir pour faire face aux situations d'urgence futures. Dans le but de sawver davantage de vies et de réduire les pertes financières, récemment le système a aussi "redécouvert» des concepts clé tels celui de résilience ou la notion de responsabilité vis-à-vis des populations victimes des désastres. Afin de comprendre le développement du système international de l'action humanitaire, l'article analyse un certain nombre de leçons qui ont été tirées des grandes catastrophes. Il s'interroge également sur l'effective prise en compte des leçons du passé dans la mise en ouvre des procédures d'intervention standard par le système humanitaire lui-même.
\end{abstract}

Keywords: Risk management - humanitarian response - United Nations - resilience - disaster reduction - accountability to affected populations

Mots clés : Gestion du risque - réponse humanitaire - Nations Unies - résilience - réduction des désastres - responsabilité envers les populations touchées 
When the UN system was established at the end of the Second World War, natural disaster management was clearly not foremost in the minds of its creators. As the preamble to the UN Charter states, "We the peoples of the United Nations, determined to save succeeding generations from the scourge of war, which twice in our lifetime has brought untold sorrow to mankind..." In fact, in 1945 only three agencies were created, outside of the General Assembly and Security Council: the World Bank, the International Monetary Fund, and the Food and Agriculture Organisation. Few could have imagined the extent to which risk management would come to dominate international affairs, or the number of different bodies that would pop up like mushrooms to deal with disasters over the next 70 years. Today, dozens of UN agencies and specialised organisations ${ }^{1}$ have a specific role to play in disasters and spring quickly into emergency mode in any crisis. What virtually all have in common is an orientation toward risk management, which may be defined as a systematic approach to handling uncertainty and minimizing loss.

Written from the perspective of a practitioner who has spent some 30 years working in international relief rather than from an academic viewpoint, this article examines the basic elements of risk management and then analyses a few lessons from past catastrophes, following both a thematic and chronological order, for the sake of convenience. While there are many typologies of disasters in use, the current treatment chooses only a few categories to better illustrate some of the lessons learnt or (occasionally) forgotten by the UN system.

\section{THE UN'S PERCEPTION OF RISK MANAGEMENT FROM PAST TO THE PRESENT}

Over the course of the past half century, the UN's perception of risk management has changed dramatically. During the 1970s and 1980s, it was common for international aid agencies to refer to the "emergency-development continuum." The model

1. World Food Programme (WFP), World Health Organisation (WHO), UN High Commissioner for Refugees (UNHCR), United Nations Children's Fund (UNICEF), Office for the Coordination of Humanitarian Affairs (OCHA), International Organisation for Migration (IOM), World Meteorological Organisation (WMO), United Nations Fund for Population Activities (UNFPA), UNWomen, among many others. used was a two-dimensional $\mathrm{X}$-axis running from emergency on the left to development on the right. The obvious (and completely erroneous) implication of this simplistic model was that nations had only to move in linear fashion out of the phase of emergencies and disasters to proceed methodically toward ever-higher levels of development. The model also engendered a dangerous view of the two realms as separated in chronology and context. As a result, many UN agencies established separate divisions within their own house, one for responding to emergencies and another for promoting social and economic development. This policy effectively prevented any integrated planning for long-term management of risk.

During the 1980s, with the onset of several "complex humanitarian emergencies" in sub-Saharan Africa, the model was modified to reflect a cyclical vision of risk management. According to this view, the cycle proceeds in orderly fashion from risk mitigation activities, to on-going preparedness and early warning efforts, to emergency response, and through early recovery to eventually reach a stable process of development. While better than the linear model, this graphic overlooks several unfortunate conditions that characterize emergencies in the real world, for instance, that different moments in the cycle may occur simultaneously in the same country; that the steps do not necessarily proceed in a neat, orderly, or cyclical manner; and that some emergencies become so structurally entrenched that the desideratum of risk-informed development is never reached.

The concept of risk management gradually became a part of most UN agencies' mandates at the beginning of this century, thanks in large part to the work of the International Strategy for Disaster Reduction (ISDR). After mixed successes in responding to disasters during the 1970s and 1980s, the General Assembly created the ISDR in 1999, as a specialised body of the UN, whose role is to raise awareness and spur action by all nations on risks and threats ${ }^{2}$.

\footnotetext{
2. The ISDR also published a definitive glossary of terms relating to risk management (UNISDR, 2009).
} 


\section{A TYPOLOGY OF HUMANitarian DISASTERS AND LESSONS LEARNT}

As the UN agencies gained experience with disasters, and recognized both the human and financial costs that these incur, there was a gradual and growing concern over how to mount an orderly humanitarian response to the cataclysmic shocks that affect nations. It should be noted that most UN agencies tend to consider displacement, conflict, health emergencies and natural disasters as simply various aspects of the same phenomenon, different types of risk to be managed. This explains why, when recounting the iconic events of humanitarian response, the first date that registers is not a natural disaster but the Biafran famine, from 1967-1970.

\section{Food Security and Nutritional Risks}

Famine-widespread hunger that directly affects the nutrition, health and survival of a populationusually has little to do with the actual availability of food in a country. That famine is a political phenomenon rather than a natural catastrophe may seem obvious to us today, but it was the research and writings of Nobel economist Amartya Sen (1981) on authoritarianism and famine that brought to light the political origins of natural disasters.

The specific case of Biafra, a civil war that broke out in 1967 between the Federal Government of Nigeria and the Eastern province on the Niger Delta, was perhaps the first famine to unfold in the era of the United Nations, and it galvanized the international community in a way that no previous humanitarian crisis had managed to do. While the UN did not officially intervene with humanitarian aid in this conflict, many individual aid workers did, including the future founders of important international non-governmental organizations like France's Bernard Kouchner of Médecins sans Frontières; Ireland's Father Angus Finucane, founder of Project Concern; and the Texan "master of disaster," Frederick Cuny of Intertect. Biafra was also one of the first humanitarian emergencies in which images of children dying of hunger caught the world's attention on the nightly news. One of the great lessons of the Biafran famine was precisely this, of the immense power of the media, a lesson which every UN agency has since institu- tionalized through the creation of communications departments and guidelines on the ethical use of the media.

During the decades from 1960 through 1980, the recurrent cycle of flood, drought, failed harvest and famine became an iconic image of the Horn of Africa. The 1974 drought in Ethiopia was not the worst in that nation's history by far, in that "only" 300,000 persons died (by comparison, one decade later, the drought of 1984 killed some 400,000 Ethiopians.) In 1974, there was no lack of food to supply the Wollo region of Ethiopia, but rather a lack of access and distribution mechanisms. While the Government controlled the famished population with an iron fist, other parts of the country enjoyed an excess of crop production. Thus, the 1974 drought reinforced to the international community and the United Nations agencies who responded to it, the notion that the solution to a famine may be political rather than humanitarian. The evident structural inequalities coupled with Ethiopian monarch Haile Selassie's inefficient management of the natural disaster led in part to his overthrow in a violent coup the same year. This series of events implanted a second important lesson that the UN seems to have understood almost intuitively: that poorly managed disaster responses can lead to revolutions or sudden political change ${ }^{3}$.

\section{Epidemic Disease Risks}

In 1971, the war of separation between East and West Pakistan gave birth to Bangladesh, currently the seventh largest nation on the planet, and, in the process, displaced some forty million persons, a quarter of these across the border and three quarters internally within what was then East Pakistan. Cholera and other forms of acute diarrheal disease became a principal cause of mortality. One of the key lessons to emerge from the work of humanitarians during this conflict was the demonstration by Bangladeshi doctors that a simple mixture of salt, sugar and clean water could save the life of a patient ill with diarrhoea. The use of oral rehydration salts (ORS) managed to reduce child mortality among

\footnotetext{
3. For other instances of this same phenomenon, it may be instructive to examine the fall of President Anastasio Somoza in Nicaragua a few years after the 1972 earthquake, or the election of Barack Obama following the bungled response by US President George W. Bush to Hurricane Katrina in 2005. Cf. Walsh, 2015.
} 
displaced Bangladeshi civilians from $30 \%$ to $3 \%$ in a relatively short period, and was quickly added to the emergency response toolkit of UN agencies. This discovery of the efficiency of ORS in managing diarrheal disease would contribute over the next four decades to the halving of child mortality worldwide, not just in disasters and catastrophes but in situations of extreme poverty as well.

Two decades later, cholera again become impressed on the consciousness of the humanitarian community in the fragile border area between Rwanda and what was then Zaire. The tragedy of the Rwandan genocide of 1994 has been well documented in both the academic and popular press, but less well publicized was the secondary disaster that occurred as a consequence of the mass flight of Hutu civilians out of Rwanda in June of 1994. Even as the triumphant Tutsi army marched into Kigali to take control of the country, close to one million persons fled across the western border into the area of North Kivu, DRC. On the rocky volcanic slopes around Goma, on the shores of Lake Kivu, dozens of spontaneous refugee camps sprang up to shelter the civilian population that arrived, fleeing Rwanda in haste and without supplies. The water sources quickly became contaminated and cholera broke out among the population. During the months that followed, men, women, children and elders were trapped with insufficient water, medical treatment, or humanitarian relief, and thousands died. In Goma, during the month of July 1994, humanitarians working in the refugee camps found some of the highest crude mortality rates ${ }^{4}$ ever recorded, ranging from 25 to 50 deaths per 10,000 persons per day (Toole and Waldman, 1997, p. 288). The lesson for the United Nations agencies was a reminder of the direct link between a displacement emergency and an ecological public health nightmare.

Unhappily, only four decades after Bangladesh, and a scant two decades after the Goma mortality, cholera proved deadly once more in the post-disaster setting of the devastating earthquake in Haiti in 2010 (described hereafter). This episode underlined that fact that lessons must be learned and re-lear-

4. Public health in a disaster situation is usually measured in terms of the crude mortality rate, or the number of deaths divided by the average population per 10,000 persons. The threshold for a public health crisis has been defined as one death per 10,000 persons of a given population per day. Thus, in a refugee camp of 90,000 persons, nine deaths in 24 hours is considered borderline normal. ned: prevention and control of cholera post-disaster requires constant monitoring, rapid public health action, strong coordination between various sectors (health, water, nutrition and education) and, above all, transparency to ensure that public health messages are disseminated.

\section{Hydro-meteorological Risks}

In November 1998, toward the end of the annual tropical storm season in the Atlantic, a catastrophic hurricane hit the Caribbean coast of Central America. Hurricane Mitch parked itself over Honduras and dropped intense precipitation on the country, then moved slowly during nine days, across Nicaragua, El Salvador and Guatemala. All four nations suffered flooding, mudslides and disease. The final balance of casualties reached over 10,000 dead or disappeared, two million persons left homeless, and material damages valued at over US $\$ 6$ billion, making Mitch one of the most devastating hurricanes in Central American history. The immediate cause of the destruction was obvioushurricanes affect the region annually between June and November-but the underlying causes included factors such as environmental degradation, soil erosion, concentration of land in the hands of a few, and economic policies of exclusion. Geographer Pascal Girot (2002) has defined this as structural vulnerability, "a combination of settlement on marginal lands, ... subsistence dependence, lack of alternatives, degree of isolation, lack of transport infrastructure, and lack of government or other support to enhance the resilience of buildings, infrastructure and livelihoods." The take-away lesson for the UN system was that social, political and economic choices by governments and societies create and perpetuate patterns of vulnerability that can intensify disasters. Moreover, disasters affect a population differentially according to age, ethnicity, gender and social class (The World Bank, 2001).

\section{Seismic Risks}

Earthquakes and tsunamis constitute perhaps the only type of rapid-onset disaster that may occur with no advanced warning at all. The catastrophic earthquake that shook Guatemala on 4 February 1976 (7.6 on the Richter scale) caused instantaneous 
widespread destruction across the country, resulting in 23,000 deaths and the loss of housing and social infrastructure on a huge scale. Frederick Cuny (1983), mentioned above, strenuously opposed the massive importation of grain and blankets by international relief organizations (a standard practice until that time), arguing that this would compete unfairly with local farmers and weavers. He also recommended the extension of low-cost construction techniques to strengthen the adobe housing of indigenous peasants, which were frequently damaged in earthquakes. The clear lesson from the disaster was that local efforts should be supported rather than replaced, building onto existing coping mechanisms, in order for external aid to "do no harm." This dictum has since been incorporated into the ten principles of the international code of conduct for NGOs and UN agencies.

Nearly 30 years later, the earthquake that shook the west coast of Sumatra on 26 December 2004 (9.1 on the Richter scale) was the third largest quake ever recorded in human history, producing a series of tsunami waves that rolled across the Indian Ocean and Bay of Bengal, affecting 14 countries, from Indonesia and Thailand all the way to Somalia in the Horn of Africa. Some 227,000 persons died and 1.7 million were displaced, and the disaster caused an estimated US\$9.9 billion in damages (Leoni, 2014). Among other lessons, the Indian Ocean tsunami reinforced the importance of early warning systems (Oxfam, 2014). While earthquakes cannot be predicted, tsunamis frequently offer a lead time from initial tremor to destructive oceanic surge. Given that there were nearly nine hours between the first quake and the monster wave that finally washed up on the east coast of Africa, a regional system to sound the alarm could have saved lives. In effect, such systems are now in place in various parts of the globe. Finally, the tsunami clearly underlined the need for better communication between scientists and political leaders on key issues of risk management, a lesson "more honor'd in the breach than the observance", by certain governments that still deny climate change.

Some students of disaster management consider the catastrophic earthquake in Haiti of 12 January 2010 as the moment when the UN lost its innocence. The bare facts of the event are well known: a 7.0 quake struck the poorest country in the
Americas, close to the intersection of the Caribbean and North American tectonic plates. The Haitian Government estimated that nearly a quarter of a million persons died within minutes of the disaster, although other sources cite figures roughly half that size. The humanitarian response was complicated, essentially, by poverty: Port-au-Prince is a vertical city with poor roads; outdated water, sewerage, health and utility services; unenforced building codes; and extremely precarious structures. Houses and hospitals collapsed, communications networks fell and the airport and harbour suffered structural damages. Many government structures were critically damaged, including the Palace of Justice, Supreme Court, National Assembly and Presidential Palace.

For the UN system, the loss was intensely personal: the offices of the World Bank and the UN Stabilization Mission in Haiti (MINUSTAH) were destroyed and some 100 UN officials were killed or disappeared under the rubble. Within seconds, humanitarians found themselves in the position of victims as well as responders. An object lesson was brought home to the UN system about the need to plan for business continuity well in advance of disasters, including back-up mechanisms for communications, housing, logistics, staff security and connectivity, as a necessary cost of doing business in risk-prone environments.

One additional, and perhaps the most painful, lesson of the Haiti earthquake was that the roll-on effects of poor risk management can follow hard on the heels of an initial natural disaster. Some ten months after the devastating quake of 2010 , cholera was re-introduced into Haiti after nearly a century of absence, ironically, by a battalion of UN peacekeepers. To date, tens of thousands of Haitians have been sickened and an estimated 9,000 have died from cholera; the disease would appear now to be endemic. This constitutes one of the worst "unintended consequences" than can unfold in the aftermath of disaster and is certainly one for which the UN system bears a heavy responsibility.

\section{Current Prospects for disAster MANAGEMENT BY THE UN SYSTEM}

Where does the United Nations stand now in terms of risk management? Over the course of seve- 
ral decades, UN agencies have managed to establish strong, functioning protocols and systems to take action on risk management. The ISDR, among other important tasks, has the responsibility for implementing the Sendai Framework for Action (20152030), which aims to push UN agencies to ensure that development projects incorporate risk mitigation into their plans and activities at national and community levels, e.g., schools that will not collapse during earthquakes and water systems that take into account extreme climatic events.

The Inter-Agency Standing Committee (IASC), established in 1992 by the UN General Assembly to strengthen the coordination of humanitarian assistance, has grown into the principal mechanism for collective decision-making on disasters and emergencies. Participating organisations include a dozen of the most important UN agencies, Red Cross organisations and three of the largest confederations of NGOs. At the highest level, the IASC Directors (the Executive Directors of each of the organisations) must convene within 48 hours of any major disaster to determine whether to categorize it as a Level 3 (L3) system-wide emergency - the highest level of humanitarian disaster-which entails specific, mandatory protocols on the part of all agencies ${ }^{5}$. The IASC also convenes regular meetings of the Emergency Directors of each participating agency, to share information on early warning, preparedness and response to specific emergency contexts around the world.

At national level, UN Resident Coordinators and Humanitarian Coordinators increasingly use risk reduction as a yardstick to evaluate the work of UN agencies in country. UN Country Teams routinely conduct simulation exercises to scale up their capacity to respond to disasters, with the full participation of host governments, NGOs, specialized agencies and donors. Some of the most important lessons learnt from emergencies past-harnessing the mass media, doing no harm, building on local efforts, coordination of all actors, investing in business continuity, and paying attention to unintended consequences-have become enshrined in the emergency manuals of the principal UN agencies as well as the IASC.

5. The decision on declaring an L3 is based on five criteria: scale, complexity, urgency, capacity, and reputational risk.
But has the UN really taken these lessons to heart? In the humanitarian sector, international civil servants rotate to new countries every few years, and the current "buzz-word" tends to change with similar frequency. Over the past three decades, the UN has touted appropriate technology, publicprivate alliances, civil-military collaboration, good humanitarian donorship, early recovery, capacity strengthening, sustainability and durable solutions. Each concept has had its day, only to be replaced by a new phrase reflecting the latest twist of humanitarian theory. In recent years, two ideas have emerged as the "new" panaceas: i) accountability to affected populations, and ii) resilience-building. These two concepts can be translated into practices as simple as prior consultation with beneficiaries when planning humanitarian interventions (e.g., where to locate the water points and health posts), or designing a response around existing local institutions and practices (e.g., making use of indigenous knowledge when promoting early warning). What seems particularly salient about these "innovations" is that they are not really new at all: they merely restate the importance of considering the views and capacities of beneficiaries when planning humanitarian response, which is simply good development practice in the first place.

\section{Conclusion}

The United Nations system has made tangible progress in disaster prevention, response and recovery. Nevertheless, the prospect for humanitarian risk management is not an optimistic one. Current trends would seem to indicate that the frequency, dimensions and impact of disasters are all growing rather than decreasing, due to a number of global factors: climate change, population growth, urbanization, social disparities, as well as the changing demographic patterns and epidemiological profile of societies. Particularly depressing is the recognition that many of the seemingly indelible lessons from disasters past must be re-learnt by each new generation of humanitarian workers. As resources dwindle and the cost of responding to disasters increases, the United Nations system would do well to heed these lessons of the past, if it is to avoid repeating errors in future humanitarian responses. 


\section{References}

Cuny F.C., 1983. Disasters and Development, New York, Oxford University Press and Oxfam, $272 \mathrm{p}$.

Girot P.A., 2002. Overview B: Environmental Degradation and Regional Vulnerability: Lessons from Hurricane Mitch, in Matthew R., Halle M., Switzer J. (ed.), Conserving the Peace: Resources, Livelihoods and Security, International Institute for Sustainable Development and IUCN the World Conservation Union, Winnipeg, Manitoba, p. 275-324.

Leoni B., 2014. A decade after Indian Ocean Tsunami, lessons learned, UNISDR Bulletin. [https://www.unisdr.org/ archive/41635].

Oxfam 2014. The Indian Ocean Tsunami: Ten Years On, Oxford, Oxfam Research Reports. [https://www.oxfam.org/sites/ www.oxfam.org/files/file_attachments/the_indian_ocean_ tsunami_10_years_on_-_lessons_from_the_response_and_ ongoing_humanitarian_funding_challenges.pdf].
SEN A., 1981. Ingredients of Famine Analysis: Availability and Entitlements, The Quarterly Journal of Economics, no 96, vol. 3, p. 433-464.

The World Bank, 2001. Hurricane Mitch-the gender effects of coping and crises, The World Bank PREM Notes, no. 57, August. [http://wwwl.worldbank.org/prem/PREMNotes/ premnote57.pdf].

Toole M.J., Waldman R.J., 1997. The Public Health Aspects of Complex Emergencies and Refugee Situations, Anmual Review of Public Health, $\mathrm{n}^{\circ}$ 18, p. 283-312.

UNISDR 2009. Terminology on Disaster Risk Reduction, UNISDR, Geneva, 30 p. [http://www.unisdr.org/files/7817_ UNISDRTerminologyEnglish.pdf].

Walsh K.T., 2015. The Undoing of George W. Bush, US News and World Report, [http://www.usnews.com/news/ the-report/articles/2015/08/28/hurricane-katrina-was-thebeginning-of-the-end-for-george-w-bush]. 